\title{
Histo-epidemiological profile of breast cancers among women in the Central African Republic: about 174 cases
}

Augustin Balekouzou ${ }^{1,4}$, Ping Yin ${ }^{1 *}$, Cavin Epi Bekolo², Christian Maucler Pamatika ${ }^{3}$, Marceline Djeintote ${ }^{4}$, Sylvain Wilfrid Nambei ${ }^{5}$, Bertrand Ba-Mpoutou ${ }^{4}$, Dieubeni Rawago Mandjiza ${ }^{4}$, Chang Shu', Minghui Yin ${ }^{1}$, Tingting Qing ${ }^{1}$ and Boniface Koffi ${ }^{3}$

\begin{abstract}
Background: Breast cancer (BC) is the most common cancer in women worldwide and leading cause of cancer deaths indeveloping countries. There is very limited data on BC in the Central African Republic. The purpose of this study was to describe the epidemiological and histopathological characteristics of BC in Bangui.

Methods: This retrospective study reviewed cancer data registries and medical records from the Pathology Unit of the National Laboratory in Bangui and the General Surgery and Gyneacology service from 2003 to 2015. A questionnaire was designed to collect information and data was analysed using descriptive and inferential statistical methods.

Results: In total, 174 cases of BC were recorded, with an average annual frequency of13.4 cases per year. The age of the women at diagnosis varied from 16 to 90 years with a median of 45.5 years and InterQuartile range (IQR) 18 years. The age group of $45-54$ years represented the majority of the study population ( $n=51,29.3 \%)$.About 25.9\%ofthe patients were non-educated and $85.6 \%$ lived in cities. Over $48 \%$ of the women were housewives with a moderate economic status $(n=99,56.9 \%)$. Sixty nine percent of the specimens received at the pathology unit were pieces of breast tumour. Invasive ductal carcinoma $(n=113,64.9 \%)$ was the main histological form and most of the tumours were of Grade III $(n=14,46.7 \%)$. The only imaging assessment was ultrasound performed in $(n=53$, $30.4 \%)$ women. Surgery was performed in $(n=166,95.4 \%)$ patients, while $(n=159,91.4 \%)$ received complementary chemotherapy. At the end of the study, $84.5 \%$ of the cases had died, $12.1 \%$ were alive and $3.4 \%$ were considered "lost to follow-up".

Conclusion: $\mathrm{BC}$ is an important public health problem and affected most of the younger Central African women. Epidemiological and histological characteristics are more or less common to those described other developing countries. It is imperative to improve the awareness of health care institutions and women on the burden of $\mathrm{BC}$, to carry out early screening of BC, and to strengthen the capacity of women's health care system.
\end{abstract}

Keywords: Breast cancer, Women, Epidemiology, Histology, Central African Republic

\footnotetext{
* Correspondence: pingyin2000@126.com

${ }^{1}$ Department of Epidemiology and Biostatistics, School of Public Health,

Tongji Medical College of Huazhong University of Sciences and Technology,

Hangkong Road 13, Post Box 430030, Wuhan City, Hubei Province, China

Full list of author information is available at the end of the article
}

(c) The Author(s). 2018 Open Access This article is distributed under the terms of the Creative Commons Attribution 4.0 International License (http://creativecommons.org/licenses/by/4.0/), which permits unrestricted use, distribution, and reproduction in any medium, provided you give appropriate credit to the original author(s) and the source, provide a link to the Creative Commons license, and indicate if changes were made. The Creative Commons Public Domain Dedication waiver (http://creativecommons.org/publicdomain/zero/1.0/) applies to the data made available in this article, unless otherwise stated. 


\section{Background}

Breast cancer (BC) is the most commonly diagnosed cancer in women worldwide. It is the leading cause of death from cancer in most developing countries. With about1.7 million new cases diagnosed in 2012, it represents $23.0 \%$ of cancers in women and $11.9 \%$ of all human cancers in the world [1]. The majority of newly diagnosed cases occurs in developing countries and affects more than one in ten women. Its incidence has increased significantly over the last two decades to $2.0 \%$ per year [2]. It is less ascertained in African and Asian women than in Europe and the United States [3]. BC is less common among the population under 25 years [4]. $\mathrm{BC}$ has a high morbidity and mortality when not diagnosed and treated early.

Incidence rates vary from one region to another throughout the world [5]. In Africa and East Asia it was 27 per 100,000, while in Europe it represented 96 per 100,000 [5]. In 2011, the annual incidence in SubSaharan Africa (SSA) was 22 per 100,000 women [6]. The incidence of $\mathrm{BC}$ increases from 35 years, peaking at 60 [7]. The study conducted in Mali in 2010, reported the regional variability with $4.0 \%$ in Kenya, $10.0 \%$ in South African Republic and $16.0 \%$ in Senegal [8]. In Niger, BC represented $34.4 \%$ of all cancers in 2012, and was the first cancer in women [5]. In addition, Mali and Cameroon $\mathrm{BC}$ is ranked second among women after cervix cancer with $21.6 \%$ and $25.9 \%$ respectively [9].

According to the 2014 report by the World Health Organization (WHO), BC is ranked first of all cancers diagnosed in the CAR with 504 cases and the leading cause of death $(24.5 \%)$ among Central African women $[10,11]$. Nowadays, the survival rate has improved in developed countries through the practice of screening and progress observed in the areas of treatment. In most SSA countries, the fight against BC is still embryonic because there is no appropriate structure for the management of identified cases and human resources are insufficient. These reasons make it difficult to implement epidemiological surveillance of $\mathrm{BC}$ in this part of the globe.

Our multicenter study had as objective to identify all cases of $\mathrm{BC}$ diagnosed at the Pathology Unit of the National Laboratory in Bangui, to describe their epidemiological and histopathological characteristics in order to inform decisions aimed at better diagnosis and management of $\mathrm{BC}$ in CAR.

\section{Methods}

The methodology used was the modified version of the Epidemiology of breast cancer: retrospective study in the Central African Republic already used by Augustin Balekouzou et al. [12].

\section{Study population}

This was a retrospective study on the primary data collected from patients' records at the Pathology Unit of the National Laboratory of Clinical Biology and Public Health in Bangui, the General Surgery and Gyneacology Services of the Friendship Hospital and the Community Hospital from September 2003 to September 2015. The cases were confirmed by histological or cytological analysis during the study period. The following participants were excluded: aged $<15$ years old, not residing in the CAR territory, and all those whose diagnosis date was outside the study period. The study was approved by the Institutional Review Board of the School of Public Health, Tongji Medical College of Huazhong University of Science and Technology (IRB Approval File No.[2014] 09), and the Scientific Committee for study protocols validation of the Faculty of Health Sciences (FACSS) of the University of Bangui (No 2070 / UB / FACSS / CSCVPER / 16). Individual patient consent was not required due to the retrospective nature of this study.

\section{Data collection}

A questionnaire was designed to collect information initially from the cancer register of the Pathology Unit of the National Laboratory; and from the medical records of patients in General Surgery and Gyneacology services. The information included: socio-demographic characteristics, such as age, occupation, economic status, education level, areas of residence, ethnic group, marital status, parity, menopausal and hormone therapy. The average annual frequency was calculated by the total number of $\mathrm{BC}$ diagnosed during the study period divided by the sum of the years during the same period. The clinical and histological characteristics were: location of the $\mathrm{BC}$, nature of the sample, histological type of the tumour, grade of the tumour, treatment and course of the disease.

\section{Diagnosis of breast cancer \\ Clinical diagnosis}

Clinical procedures for $\mathrm{BC}$ diagnosis were based on identifying a breast lump, skin texture, appearance or direction of the nipple, any unusual discharge and any rash or crusting of the nipple.

\section{Pathology technique}

The samples analyzed were mainly composed of chirurgical specimens (biopsy) and cytological specimens (aspiration by needles) fixed in $10 \%$ formalin and processed according to the usual techniques of paraffin embedding, microtome cutting and staining with hematoxylineosin. As for the detection of Ductal carcinoma in situ (DCIS), a breast ultrasound can show whether an abnormal area is solid (made of cells) or is a cyst filled with fluid. In the 
absence of imaging, a breast biopsy would be required to examine the tissue or cells under a microscope to search for cancer cells.

\section{Classification criteria}

Age was recoded as age groups (15 to 24 years, 25 to 34, 35 to 44,45 to 54,55 to 64,65 to 74,75 to 84 , and > or $=85$ years). Women who did not have a profession were classified as housewives.

The economic status was defined in terms of family income according to the international poverty threshold. Income is poor if it is below 2 dollars a day; moderate between 2 and 4 dollars; good between 5 and 10 dollars and excellent if it exceeds 10 dollars [13]. The residence was classified urban for those living in Bangui and rural for those living in the provinces (before diagnosis for $\mathrm{BC})$. Ethnicity has been grouped into thirteen major groups in the Country (Banda, Gbaya, Mandjia, Sara, Yakoma, Gbanziri, Peulh, Goulha, Mbati, Ngbaka, Gbanou, Kaba and Zande). The level of education has been classified as illiterate, elementary, secondary and university. Marital status was classified as married, single, divorced and widowed. Parity was determined by the number of completed pregnancies in a woman surveyed before diagnosis. A woman who has never had a fullterm pregnancy was considered nulliparous, while a woman with at least one to two full-term pregnancies was considered pauciparous.

The histopathogenic grade of Scarff-Bloom-Richardson (SBR) was used to specify the degree of cell differentiation of tumours on pathological examination [14].

\section{Statistical analysis}

Data analysis was performed using the Statistical Package for Social Sciences (SPSS Inc., Chicago, IL, USA) version20. Descriptive analysis was performed to characterise the demographic variables of the patients. InterQuartile range (IQR) and median were described for continuous variables with normal distribution and ranges for continuous variables with skewed distribution. Frequencies and proportions were used for categorical variables. Trend test was used to detect a significant change in trend with time.

\section{Results}

\section{Socio-demographic characteristics of the sample}

The socio-demographic characteristics of the patient were shown in Table 1. Globally, 174 cases of BC were identified during the study period. In total, 174 cases of $\mathrm{BC}$ were identified during the study period. The age at diagnosis for the cases ranged from 16 to 90 years with a median of 45.5 years and InterQuartile range (IQR) 18 years. Majority of the study population $(n=51,29.3 \%)$ represented the age group of 45-54 years followed by 3544 years $(n=49,28.2 \%)$. Most patients $(n=85,48.9 \%)$
Table 1 Socio-demographic characteristics of the sample

\begin{tabular}{|c|c|c|}
\hline Variables & Freq (174) & Percent (\%) \\
\hline \multicolumn{3}{|l|}{ Age-group (year) } \\
\hline $15-24$ & 6 & 3.4 \\
\hline $25-34$ & 27 & 15.5 \\
\hline $35-44$ & 49 & 28.2 \\
\hline $45-54$ & 51 & 29.3 \\
\hline $55-64$ & 25 & 14.4 \\
\hline $65-74$ & 11 & 6.3 \\
\hline $75-84$ & 4 & 2.3 \\
\hline$>=85$ & 1 & 0.6 \\
\hline Mini, Median, & $16 ; 45.5$ & \\
\hline Maxi, IQR & $90 ; 18$ & \\
\hline \multicolumn{3}{|l|}{ Occupation } \\
\hline Housewife & 85 & 48.9 \\
\hline Employer & 53 & 30.5 \\
\hline Shopping & 30 & 17.2 \\
\hline Student & 6 & 3.4 \\
\hline \multicolumn{3}{|l|}{ Economic Status } \\
\hline Poor & 24 & 13.8 \\
\hline Moderate & 99 & 56.9 \\
\hline Good & 48 & 27.6 \\
\hline Excellent & 3 & 1.7 \\
\hline \multicolumn{3}{|l|}{ Education level } \\
\hline None & 45 & 25.9 \\
\hline Primary & 57 & 32.8 \\
\hline Secondary & 49 & 28.2 \\
\hline University & 23 & 13.2 \\
\hline \multicolumn{3}{|l|}{ Residence } \\
\hline Urban & 149 & 85.6 \\
\hline Rural & 25 & 14.4 \\
\hline \multicolumn{3}{|l|}{ Ethnic group } \\
\hline Banda & 32 & 18.4 \\
\hline Gbaya & 22 & 12.6 \\
\hline Mandja & 31 & 17.8 \\
\hline Sara & 12 & 6.9 \\
\hline Yakoma & 26 & 14.9 \\
\hline Gbanziri & 10 & 5.7 \\
\hline Peulh & 5 & 2.9 \\
\hline Goulha & 0 & 0.0 \\
\hline Mbati & 12 & 6.9 \\
\hline Ngbaka & 8 & 4.6 \\
\hline Gbanou & 2 & 1.1 \\
\hline Kaba & 12 & 6.9 \\
\hline Zande & 2 & 1.1 \\
\hline
\end{tabular}

Marital status 
Table 1 Socio-demographic characteristics of the sample (Continued)

\begin{tabular}{lll}
\hline Variables & Freq (174) & Percent (\%) \\
\hline Married & 42 & 24.1 \\
Unmarried & 128 & 73.6 \\
Divorced & 1 & 0.6 \\
Widow & 3 & 1.7 \\
Parity & & \\
$<1$ & 7 & 4.0 \\
$>=1$ & 167 & 96.0 \\
Menopausal & & \\
Yes & 72 & 44.1 \\
No & 102 & 58.6 \\
Hormone therapy & & \\
Yes & 14 & 8.0 \\
No & 160 & 92.0 \\
\hline
\end{tabular}

Freq frequency, Percent percentage, Mini minimum, Maxi maximum, IQR InterQuartile

Employee includes all sectors: public and private. Poor family status (income < 2 dollars a day), moderate (income $=3$ to 4 dollars a day), good (income $=5$ to 10 dollars per day) and excellent (income $>10$ dollars a day); Residence: Town (Bangui) and Rural (outside Bangui). Frequency was calculated by using Cross tabulation analyze

were housewives with a moderate economic status $(n=$ 99, $56.9 \%)$. Less than $(n=23,13.2 \%)$ of the study population had a university degree and $(n=149,85.6 \%)$ lived in cities. The most represented ethnic groups were the Banda $(n=32,18.4 \%)$, followed by Mandja $(n=31,17.8 \%)$ and Yakoma $(n=26,14.9 \%)$.Unmarried women made up $(n=$ $128 / 174,73.6 \%)$ of the sample, however, a major proportion $(n=167,96 \%)$ had given birth to at least one child. Menopausal women represented $(n=72 / 174,44.1 \%)$ of the sample while small proportion $(\mathrm{n}=14,8.0 \%)$ had received hormonal therapy.

\section{Histological characteristics}

According to the Table 2, the left breast was the most affected $(80.0 \%)$ than the right breast (15.0\%).The majority of the samples received and examined by the Pathology Unit were obtained in $69.0 \%$ of cases from breast lumpectomy and in $30.0 \%$ of cases from breast biopsies. The histological grade of ScarffBloom Richardson (SBR) was available for 30 patients (17.2\%). SBR III was the main grade in the commonest histological types (46.7\%). A total of $(n=166,95.4 \%)$ of the patients underwent surgery, and $(n=159,91.4 \%)$ underwent complementary chemotherapy. Breast ultrasonography was performed in $(n=53,30.4 \%)$ women. The majority $(n=147,84.5 \%)$ of the cases had died, $(n=21,12.1 \%)$ remained alive and ( $n=6,3.4 \%)$ were considered "lost to follow up". Sixty four point $9 \%(n=113,64.9 \%)$ of all cases were invasive ductal carcinoma, followed by invasive lobular carcinoma
Table 2 Distribution of the location, nature of the sample, grade, treatment and outcome of the disease

\begin{tabular}{|c|c|c|}
\hline Variables & Frequency & Percentage \\
\hline \multicolumn{3}{|l|}{ Location } \\
\hline Left breast & 16 & 80.0 \\
\hline Right breast & 3 & 15.0 \\
\hline Both breast & 1 & 5.0 \\
\hline Total & 20 & 100.0 \\
\hline \multicolumn{3}{|l|}{ Nature of the sample } \\
\hline Mastectomy & 2 & 1.0 \\
\hline Biopsy of the breast & 52 & 30.0 \\
\hline Lumpectomy & 120 & 69.0 \\
\hline Total & 174 & 100.0 \\
\hline \multicolumn{3}{|l|}{ Scarff Bloom Richardson } \\
\hline Grade I & 6 & 20.0 \\
\hline Grade II & 10 & 33.3 \\
\hline Grade III & 14 & 46.7 \\
\hline Total & 30 & 100.0 \\
\hline \multicolumn{3}{|c|}{ Treatment Chemotherapy } \\
\hline Yes & 159 & 91.4 \\
\hline No & 15 & 8.6 \\
\hline Total & 174 & 100.0 \\
\hline \multicolumn{3}{|l|}{ Surgery } \\
\hline Yes & 166 & 95.4 \\
\hline No & 8 & 4.6 \\
\hline Total & 174 & 100.0 \\
\hline \multicolumn{3}{|l|}{ Breast ultrasonography } \\
\hline Yes & 53 & 30.4 \\
\hline No & 121 & 69.6 \\
\hline Total & 174 & 100.0 \\
\hline \multicolumn{3}{|l|}{ Outcome } \\
\hline Alive & 21 & 12.1 \\
\hline Loss to follow up & 6 & 3.4 \\
\hline Dead & 147 & 84.5 \\
\hline Total & 174 & 100.0 \\
\hline
\end{tabular}

$(n=17,9.8 \%)$ and ductal carcinoma in situ $(n=10,5.7 \%)$ according to the Fig. 1.

\section{Discussion}

Access to histological diagnosis of $\mathrm{BC}$ is very problematic in most African countries like CAR. BC diagnosis is established after examination of the breast specimens for biopsy or cytology. In CAR, there is only one pathology unit located at Bangui the capital. This unit does not practice the essential immunohistochemistry to detect hormone receptors (ER, PR and HER2). In our study, the average annual frequency of $\mathrm{BC}$ reported during the 


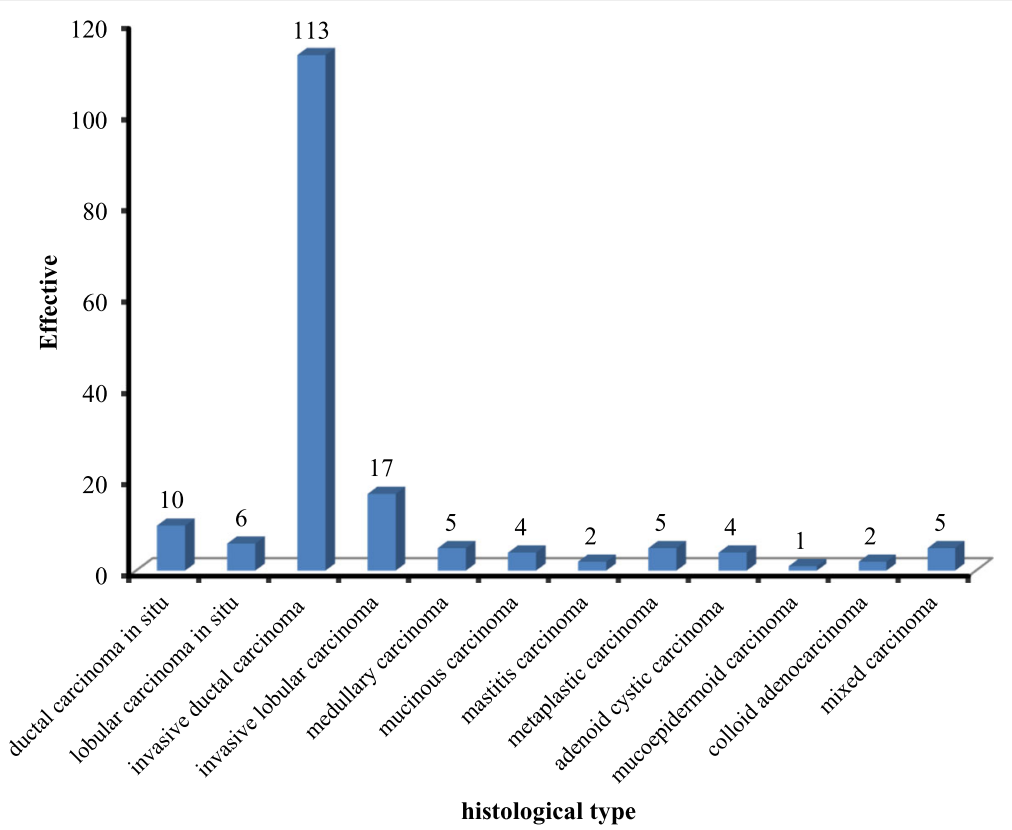

Fig. 1 Distribution of tumours according to the histological type According to the Fig. 1, the predominant BC were invasive ductal carcinoma in $(n=113,64.9 \%)$, invasive lobular carcinoma in $(n=17,9.8 \%)$, ductal carcinoma in situ in $(n=10,5.7 \%)$ and lobular carcinoma in situ in $(n=6$, 3.4\%). Medullary carcinoma and mixed carcinoma accounted for $(n=5,2.8 \%)$ of each cases

period 2003 to 2015 was 13.38 cases per year. This proportion is slightly lower than that obtained by Darré et al.(2013) in Togo who found 22.5 cases per year [15]. The age of the women at diagnosis of $\mathrm{BC}$ varied from 16 to 90 years with a median of 45.5 years. Most of the patients $(n=100,57.4 \%)$ were in the $35-44$ and 50-54 age groups. Our results corroborate the studies carried out in Bangui by Koffi et al. (2004) and by Tong Li et al. (2016) in China, but slightly above the frequency reported by Marianne Dubard-Gault in 2014 [16-18]. However in Europe and the US, the average age of women with $\mathrm{BC}$ at the time of diagnosis was about 60 years, while in SSA countries was around 45 years. This difference could be explained first by a very short life expectancy than that of the population in industrialized countries, next by an information and awareness deficit on $\mathrm{BC}$ and finally by a lot of screening in women age 50 and over in the US and Europe [2]. These findings suggest that in Africa, BC affects women at an earlier age and at an advanced stage of diagnosis and has poor outcomes. Indeed, in the present study, about twothirds of women with $\mathrm{BC}$ were in the younger age group and have presented with the disease at an advanced stage. The low frequency of $\mathrm{BC}$ in women in CAR may be due to under-medicalisation of the health care system, geographic and financial inaccessibility to health care facilities, diagnostic errors, cultural stress, disease stress, errors due to traditional medicine, ignorance of patients, shortage in cancer specialists and the absence of a program to control cancer in general and $\mathrm{BC}$ in particular. The same observation was reported in studies conducted by Koffi et al.(2003), Ben Gobrane et al., and Ekortard et al., in 2007 [19-21]. These factors constitute a barrier to the reduction of the burden of this disease in the CAR population. This is in contrast to data from developed countries where mammography screening and self-palpation is advocated. In addition, increased awareness of women has resulted in early detection of pathology. The medical-social support provided to women with BC ultimately resulted in increased adherence and survival rates for patients. This would also explain the under-representation of patients living in the rural area in this study population. It should also be pointed out that the high burden of $\mathrm{BC}$ in women aged 50 to 54 years old supports data from the literature which indicate that $\mathrm{BC}$ is a priori disease for older women.

In our study, we observed that malignant tumours predominated in the left breast. These results have also been reported by authors in previous studies in Africa $[16,22]$. But different from findings obtained from other studies where their authors reported a predominance of cancer in the right breast $[23,24]$. The frequency of the bilateral forms in our series is lower than that reported by Mengué S.(2002) in Gabon, and Khairy et al.(2005), in Saudi Arabia [23, 25]. Therefore, we do not have sufficient scientific evidence to justify the disparity of $\mathrm{BC}$ location in CAR women.

Sixty four point $9 \%(n=113,64.9 \%)$ of all cases were invasive ductal carcinoma, followed by invasive lobular carcinoma $(n=17,9.8 \%)$ and ductal carcinoma in situ 
$(n=10,5.7 \%)$. The proportion of the more common histological forms (invasive ductal carcinoma) of $\mathrm{BC}$ that we recorded was slightly below that reported by Darré et al.(2013) in Togo, and Echimane et al.(2000) in Ivory Coast, who respectively reported $96.0 \%$ and $97.0 \%$ for cancers and $2.6 \%$ and $2.04 \%$ for sarcomas [15, 26]. In Cameroon (2013) and Ghana (2015), Engbang et al., and Edmund et al., found $74.3 \%$ and $91.6 \%$ of invasive ductal carcinomas followed by $4.3 \%$ and $3.1 \%$ of invasive lobular carcinoma [27, 28]. The same trends were observed in previous study carried out in Bangui by Koffi et al.,in 2004 [16]. However, the low DCIS rate could be justified due to the lack of mammography in CAR, the only tool for early detection of BC cases.

There was a high proportion of grade III in the order of $46.7 \%$, followed by grade II (33.3\%) and grade I (20.0\%). In Ghana, more or less similar proportions have been reported by Ohene et al. (2012) [29]. These authors had found $53.7 \%$ of grade III tumours, $31.5 \%$ grade II tumours and $14.8 \%$ grade I tumours [30]. However, other studies have shown various proportions. A study by Essiben et al. (2013), found a trend in the following order of increasing frequency: grades II, I and III at the Gynecological Obstetric and Pediatric Hospital of Yaoundé [31]. In 2004, Koffi et al. in Bangui, noted that the grade II tumours were the most common with $58.4 \%$ of cases, while tumours grade I and II were in the same proportion (20.8\%) [16]. These findings differ from those reported in Gabon by Meye et al.(2004) where Grade II tumours were less common than classes III and I [32].

According to several studies, the conservative treatment of BC is offered to some patients in SSA and only a few centres perform the sentinel node technique [33, 34]. The most common surgical treatment is mastectomy with systematic lymph node dissection because the majority of tumours are diagnosed in their T2-T4 stages with lymph node involvement. In addition, surgery must be compulsorily associated with other methods of treatment including chemotherapy, radiotherapy and hormone therapy; this for the control of the general cancerous disease [35]. In our patients, $(n=166 / 174,95.4 \%)$ were treated with surgery and $(n=159 / 174,91.4 \%)$ with complementary chemotherapy. Our results were in sharp contrast to studies conducted by Gakwaya et al. (2008), where only $26.0 \%$ of patients received chemotherapy and by Serdouma et al. (2006), where $66.3 \%$ had surgery $[29,36]$. Given the socioeconomic context in the CAR, chemotherapy, although indicated for the treatment of $\mathrm{BC}$, is often faced by the problem of medicines for chemotherapy and the money to pay for them. Despite the large number of patients receiving chemotherapy, only $12.5 \%$ of the patients were able to complete their treatment cycles. Indeed, the cost of a cycle of chemotherapy was estimated at $\$ 260$, resulting in the cost of a round of chemotherapy varying from $\$ 1040$ to $\$$
1560. This cost was largely above the income of the patients according to the report of World Bank in 2015 which estimated the annual average income of the Central African is of the order of \$ 338.7 [37]. This explains inaccessibility to chemotherapy especially for drugs not available in Bangui.

Certain limitations must be considered to explain the results of this study. First, in CAR there is no cancer registry and no national cancer control program. Therefore, the incidence of $\mathrm{BC}$ per year is difficult to determine and immuno-histochemical analysis of cases has not been performed. In terms of the representativeness of the data from this research, it can be pointed out that in CAR, there is only one pathology unit for the diagnosis of cancer and one cancer department for the medical management of cases. However, we believe that the results of this study can be reported to the general target population of CAR despite the low sampling. Secondly, depending on the type of this (retrospective) study, a significant amount of our data $(n=37,14.0 \%)$ was removed due to lack of information as a result of poor records management. In addition, the death date of patients that should allow us to calculate the survival rate after diagnosis is not available. Finally, we believe that the results of this study will contribute to BC research in CAR.

\section{Conclusion}

$\mathrm{BC}$ is an important public health problem and affected most of the younger Central African women. Epidemiological and histological characteristics are more or less common to those described other developing countries, with a younger age at onset, advanced stage at diagnosis, and/or poor prognosis. Most of the patients lived in an urban area. Invasive ductal carcinoma is a predominant form of $\mathrm{BC}$ diagnosed. Therefore, it is imperative to improve the awareness of health care institutions and women on the burden of $\mathrm{BC}$, to carry out early screening of $\mathrm{BC}$, and to strengthen the capacity of women's health care system.

\section{Abbreviations}

BC: Breast cancer; CAR: Central African Republic; SBR: Scarff Bloom Richardson; SPSS: Statistical Package for Social Sciences; SSA: Sub-Saharan African; WHO: World Health Organization

\section{Acknowledgments}

The authors acknowledge the following personalities for their contributions towards the study: Professor PingYin, Catherine Samba-Panza, Nestor Tomy, LudovicNemayiri, Oscar Senzongo, Evelyne Clara Sambedemo, Michelle

Chance Malekatcha, Koffi Akpene Antony, Yapatake Pacific and Fatime Yougboko. The authors also extend their appreciation to all participants and staff of PathologyUnit of the NLCBPH in Bangui and Tongji Medical College of Huazhong University of Sciences and Technology in China for their contributions.

Funding

This study had no funding source. 


\section{Availability of data and materials}

The raw data in excel file under identification policy could be provided via the e-mail of corresponding author upon request for research purpose only.

\section{Authors' contributions}

$A B$ conceived of the study, and designed the protocol, supervised the data collection and provided writing. CMP was responsible for the data collection; $\mathrm{MD}$ and BBM participated in the epidemiological investigation. DRM carried out data analysis. CS, MY and TQ participated in the overall design, performed the statistical analysis. SWN and CEB interpreted the results and refined the manuscript. PY and BK have coordinated the work of the entire team. All authors read and approved the final manuscript.

\section{Ethics approval and consent to participate}

The study was approved by the Institutional Review Board of the School of Public Health, Tongji Medical College of Huazhong University of Science and Technology (IRB Approval File No.[2014] 09), and the Scientific Committee for study protocols validation of the Faculty of Health Sciences (FACSS) of the University of Bangui (No 2070 / UB / FACSS / CSCVPER / 16). Patient consent was not required due to the retrospective nature of this study.

\section{Consent for publication}

No applicable.

\section{Competing interests}

The authors declare that they have no competing interests.

\section{Publisher's Note}

Springer Nature remains neutral with regard to jurisdictional claims in published maps and institutional affiliations.

\section{Author details}

${ }^{1}$ Department of Epidemiology and Biostatistics, School of Public Health, Tongji Medical College of Huazhong University of Sciences and Technology, Hangkong Road 13, Post Box 430030, Wuhan City, Hubei Province, China. ${ }^{2}$ Ministry of Public Health, Central Medical d'Arrondissement de Bare, Nkongsamba, Yaoundé, Cameroon. ${ }^{3}$ Hospital Laboratory Friendship Bangui, Independence Road, Bangui City, Central African Republic. ${ }^{4}$ National Laboratory of Clinical Biology and Public Health, Abdel Nasser Road, Post Box 1426, Bangui City, Central African Republic. ${ }^{5}$ Faculty of Health Sciences, University of Bangui, Martyr Road, Post Box 1383, Bangui City, Central African Republic.

Received: 18 January 2016 Accepted: 20 March 2018

Published online: 05 April 2018

\section{References}

1. Naderimagham S, Alipour S, Djalalinia S, Kasaeian A, Noori A, Rahimzadeh S, et al. National and sub-national burden of breast cancer in Iran; 1990-2013. Arch Iran Med. 2014;17:794-9.

2. Ly M, Antoine M, André F, Callard P, Bernaudin JF, Diallo DA. Breast cancer in sub-Saharan African women: review. Bull Cancer. 2011;98:797-806.

3. Elgaili EM, Abuidris DO, Rahman M, Michalek AM, Mohammed SI. Breast cancer burden in Central Sudan. Int J Women's Health. 2010;9:77-82.

4. Dubard-Gault M. Le cancer du sein chez la femme de moins de 50 ans a la Réunion entre 2005 et 2010. Thesis 2013 [French]. In: Human Health and pathology [dumas-00967404]. URL: http://dumas.ccsd.cnrs.fr/dumas00967404/document. Accessed 15 Dec 2015.

5. Ferlay J, Soerjomataram I, Ervik M, Dikshit R, Eser S, Mathers C, et al. LOBOCAN 2012 v1.0, Cancer Incidence and Mortality Worldwide: IARC Cancer Base No. 11 [Internet] Lyon, France. In: International Agency for Research on Cancer. 2013. http://globocan.iarc.fr/Default.aspx.

6. Mandal A. Breast cancer epidemiology. In. Reviewed. Cashin-Garbutt, BA Hons (Cantab). April 2014. Save from URL: https://www.news-medical.net/ health/Breast-Cancer-Epidemiology-\%28French\%29.aspx. [French Article]

7. Bray F, Ren JS, Masuyer E, Ferlay J. Global estimates of cancer prevalence for 27 sites in the adult population in 2008. Int J Cancer. 2013;132:1133.

8. Togo A, Traore A, Traore C, Dembele BT, Kante L, Diakite I, et al. Breast cancer in two hospitals in Bamako (Mali): diagnostic and therapeutic aspects. J Afr Cancer. 2010;2:88-91. [French Article]
9. Enow Orock GE, Ndom P, Doh AS. Current cancer incidence and trends in Yaounde, Cameroon. Oncol Gastroenterol Hepatol Rep. 2012;1:58-63.

10. World Health Organization. Country profiles for cancer. 2014. In. http:// www.who.int/cancer/country-profiles/caf_fr.pdf. [French Article]. Accessed 18 Dec 2015

11. Qian F, Ogundiran T, Hou N, Ndom P, Gakwaya A, Jombwe J, et al. Alcohol consumption and breast cancer risk among women in three sub-Saharan African Countries. Fletcher O. PLoS One 2014;9:e106908.

12. Balekouzou A, Yin P, Pamatika CM, Bishwajit G, Nambei SW, Djeintote M, et al. Epidemiology of breast cancer: retrospective study in Central African Republic. BMC Public Health. 2016;16(1):1230.

13. Smelser NJ, Baltes P. International Encyclopaedia of the Social and Behavioural Sciences. In: Ebw J, editor. , vol. 15. Pergamon: Elsevier Oxford Science Ltd; 2001. eBook ISBN:9780080548050.

14. Harris L, Fritsche $H$, Mennel R, Norton L, Ravdin P, Taube $S$, et al. American Society of Clinical Oncology: American Society of Clinical Oncology 2007 update of recommendation for use tumor markers in breast cancer. J Clin Oncol. 2007;25:5287-12.

15. Darré $T$, Amegbor $K$, Sonhayé L, Kouyate $M$, Aboubarak A, N'Timo B, et al. Histo-epidemiological profile of breast cancer: about 450 cases seen at the university hospital of Lome. Méd Afr Noire. 2013;60:53-8. [French Article]

16. Koffi B, Sepou A, Doui D, Goumba C, Djabanga S. Epidemiological and histological characteristics of breast cancers in Bangui. Méd Afr Noire. 2004; 51:112-4. [French Article]

17. Li T, Mello-Thoms C, Brennan PC. Descriptive epidemiology of breast cancer in China: incidence, mortality, survival and prevalence. Brest Cancer Res Treat. 2016;159:395-406.

18. Dubard-Gault M. Breast cancer in women under 50 years old in Reunion between 2005 and 2010. Thesis of Medical Science 2013. In: Human Health and pathology [ dumas-00967404] 2014. https://dumas. ccsd.cnrs.fr/dumas-0096740. 2014. Assessed 11 Nov 2015. [French Document].

19. Koffi B, Serdouma E, Sepou A, Doui Doumgba A, Kaimba C, Djabanga SC, et al. Assessment of mammary lesions by cytopunction (4 years). Guinée Med. 2003;40:51-5. [French Article]

20. Ben Gobrane H, Fakhfakh R, Rahal K, Ben Ayed F, Maalej M, Ben Abdallaah $\mathrm{M}$, et al. Prognosis of breast cancer at the Salah Azaiez Carcinology Institute of Tunis. Eastern Mediterranean Health J. 2007;13:309-18. [French Article]

21. Ekortarl A, Ndom P, Sacks A. A study of patients who appear with far advanced cancer at Yaounde general hospital, Cameroon, Africa. PsychoOncology. 2007;16:255-7.

22. Tre-Yavo M, Sakho SS, Mensah Ado I, Yao Gnangoran V, Laurent L, Ehouman $A$, et al. The cytology of malignant breast tumors: assessment of the laboratory of cytology of the University Hospital of Abidjan. Med Afr Noire. 1992;39:62-7. [French Article]

23. Mengue S. Breast cancer in women at the hospital in Libreville. Gabon: Thesis of Medicine. University of Libreville; 2002. p. 80. [French Document]

24. Bagaza B. Contribution to the study of mammary affections in women: Epidemiological, diagnostic and therapeutic aspects: Thesis of Medicine. University of Bangui, CAR; 2003. p. 85. [French Document]

25. Khairy GA, Guraya SY, Ahmed ME, Ahmed MA. Bilateral breast cancer. Incidence, diagnosis and histological patterns. Saudi Med J. 2005;26:612-5.

26. Echimane AK, Ahnoux AA, Adoubi I, Hien S, M'Bra K, D'Horpock A, et al. Cancer incidence in Abidjan, Ivory Coast: first results from the cancer registry, 1995-1997. Cancer. 2000;89:653-63.

27. Ndamba Engbang JP, Essome H, Mve Koh V, Simo G, Sime Essam JD, Sone Mouelle A, et al. Breast cancer in Cameroon, epidemiological profile histo-epidemiological: about 3044 cases. Pan African Med J. 2015;21:7269. [French Article]

28. Edmund DM, Naaeder SB, Tettey Y, Gyasi RK. Breast cancer in Ghanaian women: what has changed? Am J Clin Pathol. 2013;140:97-102.

29. Ohene-Yeboah M, Adjei E. Breast cancer in Kumasi, Ghana. Ghana Med J. 2012;46:8-13.

30. Serdouma E, Doui Doumgba A, Koffi B, Bagaza B, Nali Mamadou N. Epidemiological and clinical aspects of breast disease in women in Bangui (CAR). Méd Afr Noire. 2006;5310:572-6. [French Article]

31. Essiben F, Foumane P, Mboudou ET, Dohbit JS, Mve Koh V, Ndom P. Diagnosis and treatment of breast cancer in Cameroon: a series of 65 cases. Mali Med. 2013;28:1-5. [French Article]

32. Meye JF, Ngomo KM, Diallo I. Breast cancer hospital in Libreville. Méd Afr Noire. 2004;51:479-82. [French Article] 
33. Wasserman LJ, Apffelstaedt JP, de V Odentaal J. Conservative management of breast cancer in the elderly in a developing country. World I Surgical Oncol. 2007;5:108.

34. Amir H, Kwesigabo G, Aziz MR, Kitrinya JN. Breast cancer and conservative surgery in sub Saharan Africa. East Afr Med J. 1996;73:83-7.

35. Breast Cancer: Treatment Option, 2005-2017. American Society of Oncology (ASCO). URL: https://www.cancer.net/cancer-types/breast-cancer/treatmentoptions. Assessed 17 Mar 2017.

36. Gakwaya A, Kigula-Mugambe JB, Kavuma A, Luwaga A, Fuala J, Jombwe J, et al. Cancer of the breast: 5 -year survival in a tertiary hospital in Uganda. Br J Cancer. 2008:99:63-7.

37. Report of the World Bank: Classement GDP. In. Edited by https://www. journaldunet.com/patrimoine/finances-personnelles/1164746-pays-pauvres/ 1191102-republique-centrafricaine; 2015. Assessed 10 Jan 2016.

Submit your next manuscript to BioMed Central and we will help you at every step:

- We accept pre-submission inquiries

- Our selector tool helps you to find the most relevant journal

- We provide round the clock customer support

- Convenient online submission

- Thorough peer review

- Inclusion in PubMed and all major indexing services

- Maximum visibility for your research

Submit your manuscript at www.biomedcentral.com/submit
Biomed Central 